\title{
Size variation of Neogene Reticulofenestra coccoliths from Indian Ocean DSDP Cores
}

\author{
JEREMY YOUNG \\ Palaeontology Department, The Natural History Museum, \\ Cromwell Road, London SW7 5BD \\ (Research carried out at Geology Dept., Imperial College, London.)
}

\begin{abstract}
Data is presented here on Reticulofenestra coccolith size distribution patterns from 122 Mid-Miocene to Pliocene samples from Deep Sea Drilling Project sites in the Western Indian Ocean and Red Sea. A clear pattern is revealed with a dramatic size reduction event occurring in the Late Miocene (nannofossil zone NN10). As a result of this event nannofloras from the interval above it are readily distinguishable by the absence of specimens longer than 5 microns; this interval is termed the "small Reticulofenestra interval". Assemblages from above and below this interval contain large specimens but they can be reliably distinguished by different size distribution patterns within them. Analogous data from other studies is reviewed, possible causes of the pattern are discussed, and its biostratigraphic application described. The Neogene taxonomy of the genus Reticulofenestra is revised and four new combinations are proposed.
\end{abstract}

\section{INTRODUCTION}

Although there are excellent high resolution nannofossil zonations for the Neogene (Martini 1971, Okada \& Bukry 1980, Theodoridis 1984) in practice they are often extremely hard to apply since many of the marker species used are rare, ecologically restricted, or vulnerable to diagenesis. In well preserved pelagic sediments these problems are not important, but in the less favourable conditions routinely encountered during applied work they can greatly reduce the biostratigraphic resolution. So it is of considerable interest to attempt to extract the maximum amount of information from the more common nannofossils. Reticulofenestrid coccoliths are particularly promising since they are the most abundant and widespread element of the nannofloras, and are diagenetically resistant.

Biostratigraphic problems of this kind were encountered during a study of the Neogene of the Makran of Pakistan (Platt et al 1985). In consequence a study was made of reference samples from Indian Ocean Deep Sea Drilling Project (DSDP) cores. In particular Reticulofenestra size variation was systematically observed. This work provided strong evidence for a surprisingly simple, consistent, and useful pattern of size variation, as described here.

\section{METHODOLOGY}

Measuring Technique. All work was carried out using conventional light microscopy, and coccolith size was measure using an eyepiece graticule. At the highest magnification (x200) the graticule divisions corresponded to 0.64 microns on the specimen, which provided the limit of resolution. This is adequate for recording variation in maximum dimension, i.e. length, since there is wide variation in length $(<3$ to $>10$ microns). This resolution is inadequate, however, for investigating variations in form, since other parameters, such as coccolith width, central area length or rim width correlate strongly with length (Backman 1980, Young 1989). Electron microscopy, or image analysis equipment, is needed to quantitatively investigate the residual variation in these parameters independent of length. Hence, in order to make measuring fast enough for routine work, only the single parameter of coccolith length was measured.

For each sample the length of about one hundred randomly selected specimens was measured. The technique was to measure about twenty specimens in one area of a slide, moving from one specimen to the nearest unmeasured specimen, then moving to another area of the slide. In all cases low density smear slides were used.

Taxa included. The reticulofenestrid coccoliths form an homogeneous group distinguished by their structure and readily recognisable by both light and electron microscopy (Fig. 1). They dominate coccolith assemblages from the Eocene to the Recent. Genera are primarily distinguishable by central area and rim structure. In the Middle Miocene to Early Pliocene interval reticulofenestrid coccoliths lack distinctive structures and show little variation other than in size and degree of central area closure. Variation in both these parameters is continuous and so it is difficult to deal with the group other than as a single plexus, the genus Reticulofenestra. Coccoliths with wall cycles that have grown inwards to close the central area are placed in a separate genus, Dictyococcites, by many authors (e.g. Haq 1971, Backman 1980, Pujos 1985 , Perch-Nielsen 1985), but not by others (e.g. Wise 1983, Driever 1988, Gallagher 1989). I support the latter view since this variation is probably ecophenotypic: intermediates occur; the closed central area forms are more common at high latitudes (Burns 1975, Haq 1980, Backman 1980, 1984); similar variation occurs within the coccoliths of the living 


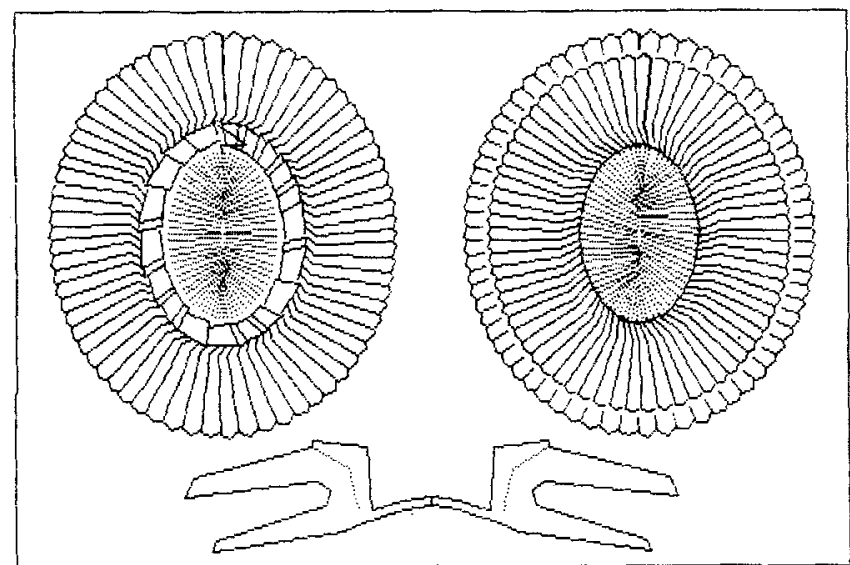

Fig. 1. Reticulofenestra pseudoumbilicus. Computer generated illustration of a typical $R$. pseudoumbilicus coccolith, seen in distal (left) and proximal (right) view, and in cross-section (below). In life the coccolithophore cell is surrounded by a coccosphere formed of several such coccoliths. The coccolith is constructed of a cycle of 30 to 60 intricate crystal units (Young 1989), but has a simple shape and shows little structural variability, Most other Neogene "species" of Reticulofenestra are essentially size defined variants of $R$. pseudoumbilicus.

species Emiliania huxleyi (Burns 1977, Heimdal \& Gaarder 1981, my obs). All encountered reticulofenestrids were included in the size counts of Middle Miocene to Early Pliocene assemblages. This had the advantage that selection of specimens for measuring was not dependent on subjective taxonomic assignments.

In the Late Pliocene there are distinctly different assemblages with the appearance of coccoliths with slits between the distal shield elements (Reticulofenestra lacunosa) and of coccoliths with a bridge across the central area (Gephyrocapsa spp.). Gephyrocapsa specimens were not included in the size counts but all members of the Reticulofenestra minutula - Reticulofenestra lacunosa group were included (see systematic taxonomy, and Fig. 9 for use of names).

Biostratigraphy. The samples were dated by combining data from the Initial Reports (Whitmarsh et al., 1974, Fisher et al.,1974, Simpson et al., 1974, Davies et al., 1974), subsequent studies (Theodoridis 1984), and my own observations (Young 1987). They were then assigned ages in Ma using the time scale of Haq et al., (1987).

\section{DATA PRESENTATION}

The raw counting data is presented in Figures 3-5, without manipulation. Each diagram gives the data from a single DSDP site as a series of compressed size / frequency histograms for individual samples. On these histograms the horizontal scale is coccolith length and the vertical scale is relative frequency. Both scales are linear, and the size intervals are those recorded (i.e. increments of 0.64 microns). Only two adjustments have been made to the data, both primarily to cope with the occasional very abundant small specimens. First, abundances have been calculated relative to the abundance of specimens over two microns, rather than of all specimens. Thus the presence of abundant small specimens in a sample does not depress the indicated abundances of the other specimens. Second, any relative abundances over 0.4 are rounded down to 0.4 , this prevents histograms overlapping. Operator bias was reduced by performing all data reduction and plotting by computer.

The vertical positioning of the histograms within the diagrams is based on the age determined by conventional biostratigraphy. Nannofossil zones, chronometric ages and sample numbers (Core-Section) are given beside the vertical axes of the diagrams. Site locations are indicated on the map (Fig. 2).

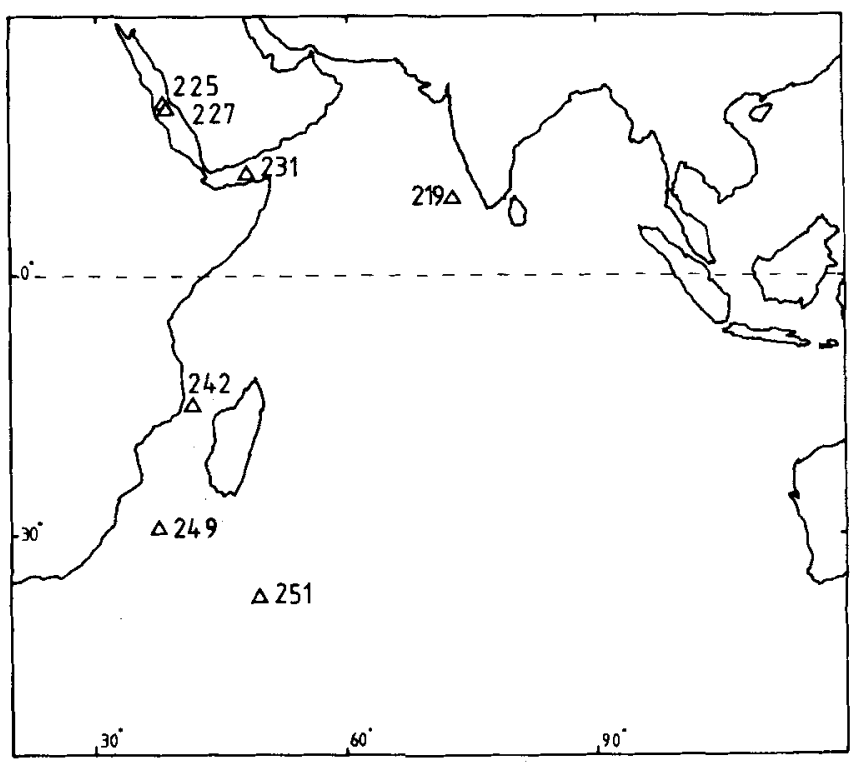

Fig. 2. The Indian Ocean.

Map showing location of the Deep Sea Drilling Project Sites from which studied material came. Mercator projection.

\section{RESULTS}

Main Results, DSDP Sites 219, 223, 231, and 242

The results from the four sites with reasonably continuous successions are given in Figures 3 and 4. These are discussed together since the results are very similar in each case; even though the sites are separated by thousands of kilometres (Fig. 2). They can be subdivided into four intervals, as discussed below, with reference to the standard nannofossil zones of Martini (1971).

A. NN6 to early NN10. The size disstribution patterns in all the samples from this interval show similar features. They are unimodal with a broad spread of sizes, typically 2-10 microns. Despite the general similarity of all the size distributions, a general trend can also be detected of size increase through this interval. This is shown particularly by variation in the modal length, maximum length is nearly constant. Thus although all samples contain significant numbers of specimens over 5 microns long these only constitute the majority of the assemblages in the later samples. 


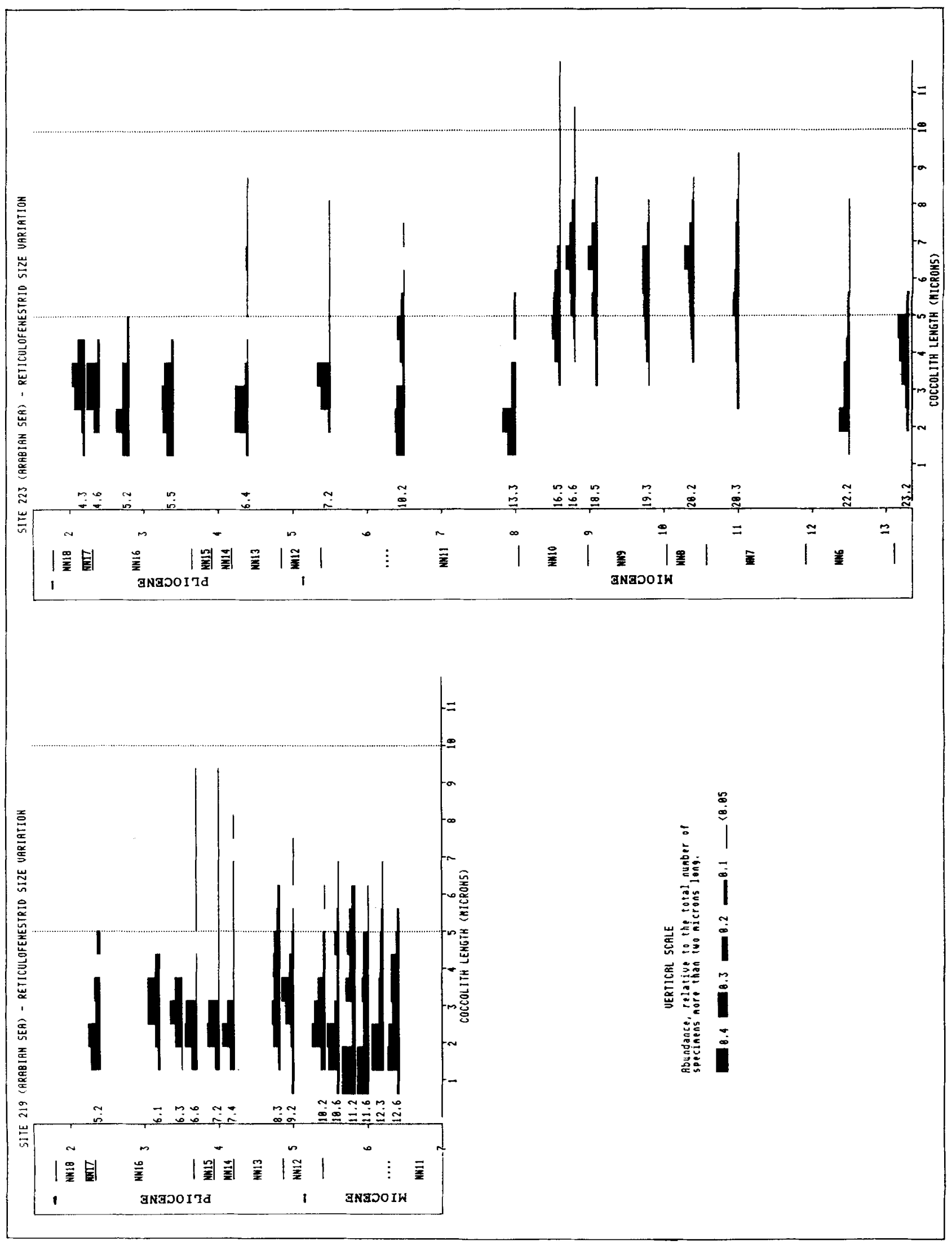




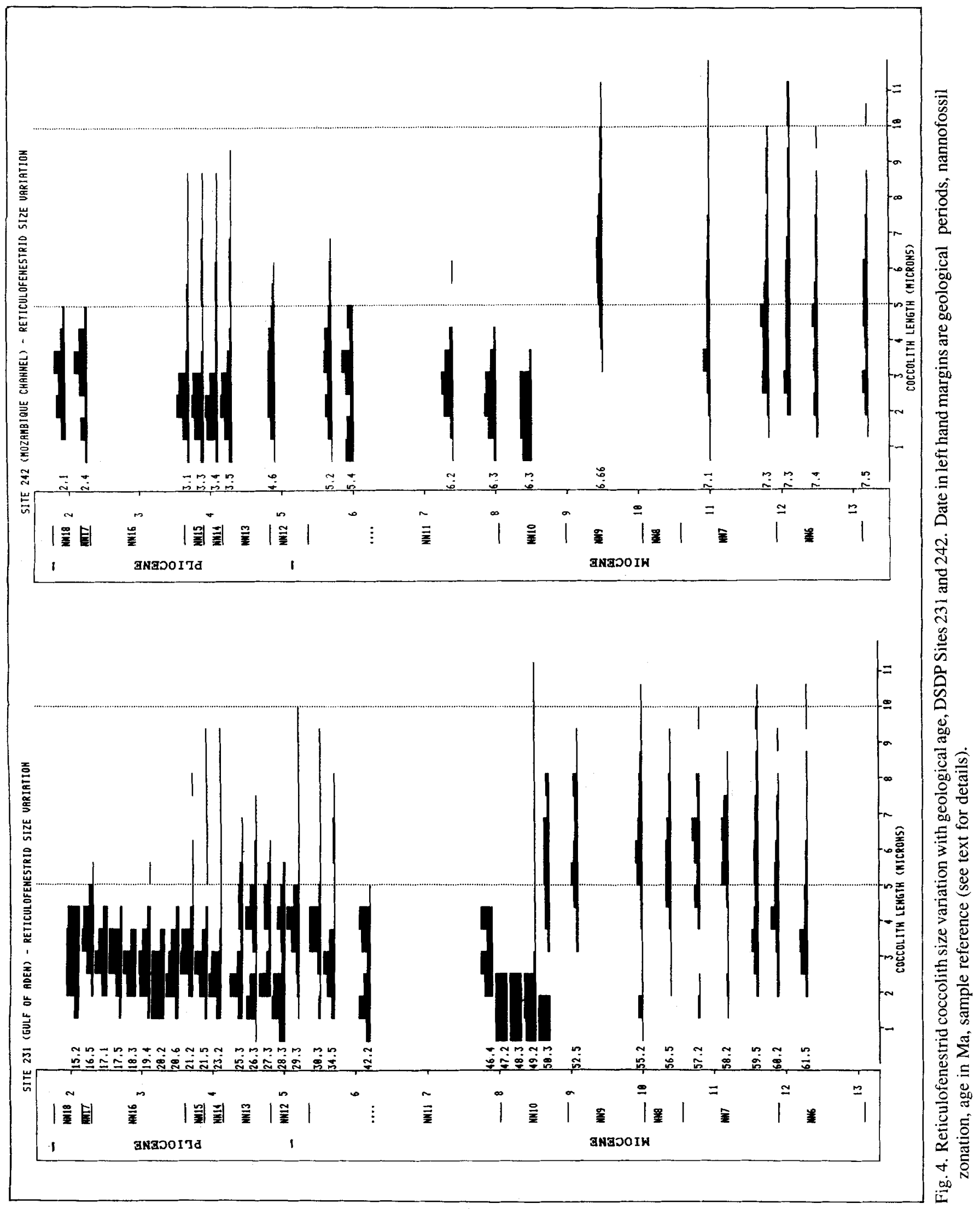




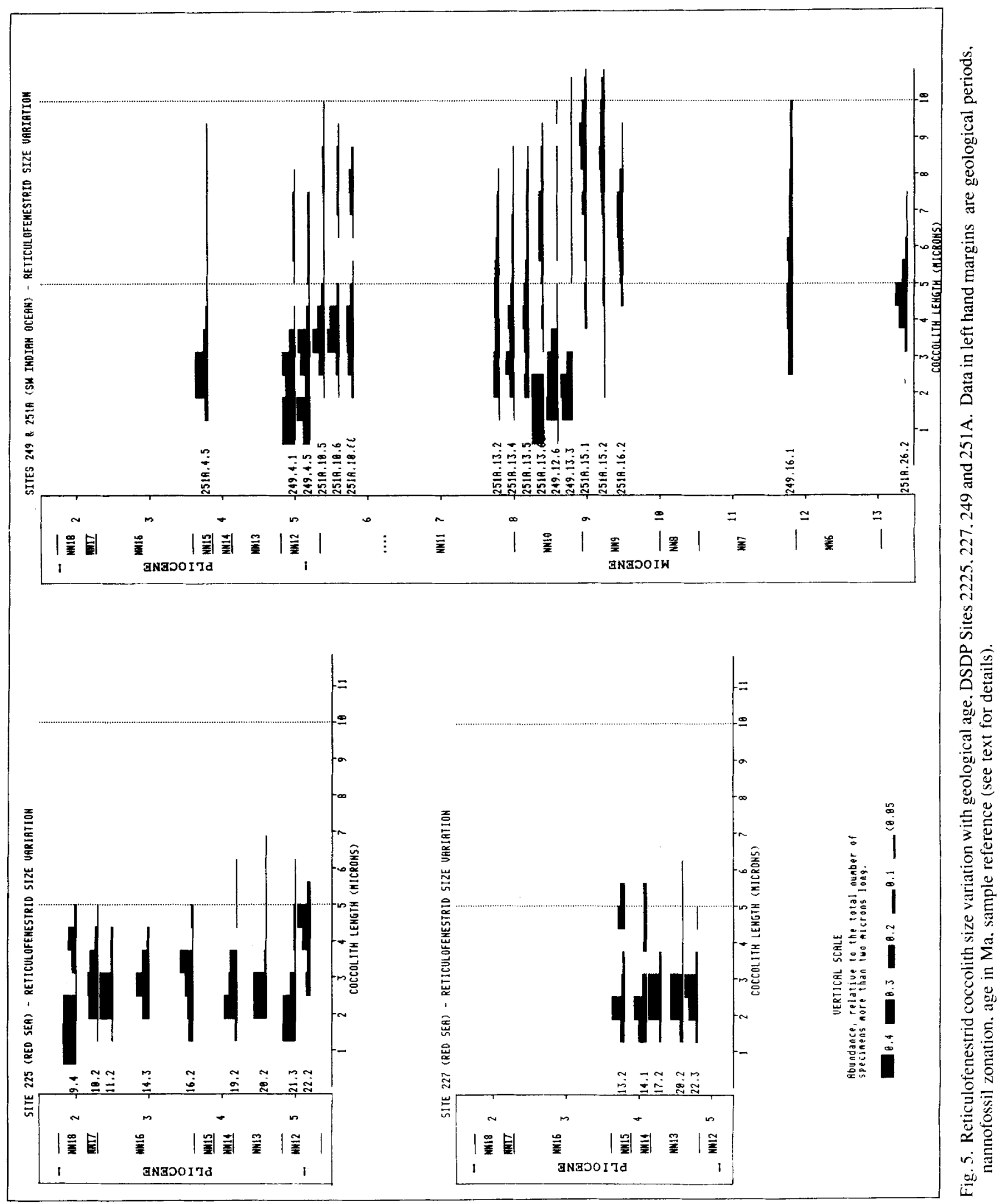


B. Late NN10 to early NN11 - "Small Recticulofenestra Interval". Within zone NN10 there is a dramatic decrease in maximum, minimum, and modal size, with coccoliths over five microns long virtually disappearing, and smaller specimens increasing in abundance (in both relative and absolute terms). The samples from this interval contain the most distinctive Reticulofenestra assemblages. For convenience I have termed it the "small Reticulofenestra interval", by analogy with the Pleistocene small Gephyrocapsa interval (Gartner 1977, Rio 1982).

C. Late NN11 to NN15. During this interval the reticulofenestrids again show a wide range of size variation, as in the first interval. The size distribution patterns, however, are strongly skewed toward the smaller specimens, so the bulk of specimens are always less than 5 microns long, and large specimens ( $>c .7$ microns) are always rare. Within the smaller size range several samples show evidence of bimodality with a frequency minimum around $3-3.5$ microns. It is thus possible to describe the Reticulofenestra coccolith assemblage in this interval as being formed of three components: very small coccoliths ( $<3$ microns): small coccoliths ( $3-5$ microns); and larger coccoliths ( $>5$ microns). There appears, however, to be a complete intergradation of morphology between the three groups.

There is some evidence of size increase through this interval, particularly in maximum length. However, this cannot be a simple uniform size increase trend since 7-10 micron long coccoliths are present in both top NN11 and NN14-15 age samples, but are generally absent from Earliest Pliocene, NN12-13 age samples. This is most clearly seen in Site 231 (Fig, 4), and was also noted in material from the Makran (unpublished data). The simplest interpretation is perhaps that there are two size increase trends separated by a minor size reduction event near the top of the Miocene. However, owing to the restricted number of samples and the low relative abundance of the larger specimens this suggestion can only be tentative.

D. NN16 to NN18, Late Pliocene. The last occurrence of $R$. pseudoumbilicus (i.e. large Reticulofenestra) is the marker event for the NN $15 / 16$ boundary. In the data this is reflected by the absence of specimens over 5 microns above NN 15 although as they are rare in any case this does not have a very marked effect on the appearance of the assemblages. In addition the subsequent assemblages are almost entirely unimodal, with the dominant size, 2.5-4 microns approximately corresponding to the frequency minimum in the previous bimodal distributions. Also larger specimens show distinctive "lacunosa" morphology (slitting between the rays of the distal shield, more open central area, and lower ellipticity).

\section{Red Sea Sites, 225 and 227}

The results from these sites (Fig. 5) are of some interest since the largest Reticulofenestra specimens are missing, possibly an ecological effect related to the restricted nature of the Red Sea at this time. Nonetheless the results are plainly comparable to those from the other sites and the last occurrences of specimens over five microns are still apparent.

\section{South West Indian Ocean Sites, 249 and 251A}

The data from these sites (Fig. 5) is limited and of rather poor quality, in particular the biostratigraphy is not as good as for the other sites, and preservation is rather worse. I did not want, however, to exclude data which was contradictory to the general model presented.

The results from the NN6-NN9 interval (samples 251A26-2 to 251A-15-1) are similar to those from the other sites. The small Reticulofenestra interval is arguably represented by samples 251 A-13-6 to 249-13-3 but since there are some large specimens still present in these samples it is much less distinct than at the other sites. The three samples above these (251A-13-2 to 251 A-13-5) have lower modal size than in the early samples, but again the presence of large specimens reduces this contrast. The youngest assemblages (Samples $251 \mathrm{~A}-4-5$ to $251 \mathrm{~A}-10-\mathrm{CC}$ ) are similar to those of this age from the other sites.

The poor development of the small Reticulofenestra interval in this area may be an artifact related to the problems noted above. Alternatively it may be related to the higher latitude of these sites $\left(35-40^{\circ}\right.$ as opposed to $\left.<25^{\circ}\right)$.

\section{COMPARABLE STUDIES}

The last occurrence of large Reticulofenestra and the end of the Early Pliocene is well established as a global event, it forms an important datum in all Pliocene nannofossil zonations. Beyond this the literature contains few explicit indications that Neogene reticulofenestrids show systematic size variation patterns. There are, however, several studies which can be used to investigate whether the patterns described above also hold outside the Western Indian Ocean.

Other biometric studies. The most extensive biometric study published on Miocene reticulofenestrids is that of Backman (1980). He did detailed work mainly on the, high latitude, N.Atlantic DSDP Site 116. His work was, however, primarily taxonomic through time (Backman 1980, figs. 5 \& 24) could be interpreted as giving evidence for a Late Miocene small Reticulofenestra interval, but is not directly comparable with mine [N.B. size data is given in terms of "placolith area", this parameter is undefined but appears to equal 2$2.5 x$ length ${ }^{2}$.

For the Pliocene Driever (1988) has recently completed a very detailed study using Mediterranean land sections. The Early Pliocene Reticulofenestra assemblages described are predominantly bimodal or negatively skewed - with abundant small specimens ( $<4$ microns) and rare large one (his figs. 1825 ). Interestingly he found that the large specimens increased in size through the Early Pliocene (NN12-15); from about 5 to 9microns (his figs. 27-28,33). These results are in excellent agreement with my, limited, data for this period (Site 231, Fig. 4 and Section 3.1C).

Quantitative studies using detailed taxonomy. From his biometric work Backman (1980) proposed a rationalized subdi- 


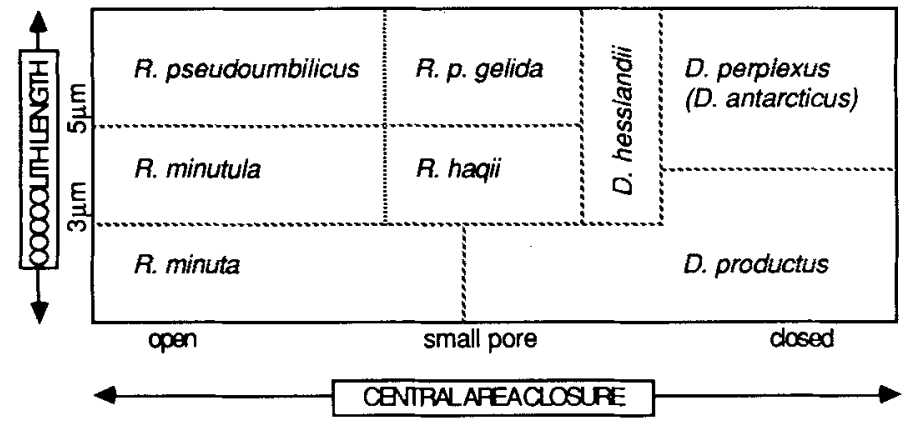

Fig. 6. Conventional taxonomic subdivision of Miocene Reticulofenestra coccoliths, after Backman (1980), Pujos (1987) etc. This classification subdivides the group according to coccolith length and degree of central area closure. Central area closure is probably an unstable ecophenotypic character and is not used in this paper. N.B.(1) The genus Dictyococcites is used for specimens with closed central areas. (2) $D$. perplexus and $D$. hesslandii are rarely reported above the Miocene. (3) $R$. doronicoides is usually used in place of $R$. minutula in the Late Pliocene. (4) The boundary sizes vary slightly between authors. (5) An emended version of this taxonomy is recommended in the systematics section (see also Fig. 9).

vision of the reticulofenestrids based on size and central area opening (summarised in Fig. 6). The scheme has been adopted by several authors, with only minor changes to the species definitions. Some of these have presented quantitative information on the species abundances which can be compared with my data.

Haq (1980) studied variations in nannofossil assemblages in 44 Miocene samples from 23 South Atlantic DSDP sites. The information is given in terms of principal components analysis so details are obscure, but major trends can be seen. The $R$. pseudoumbilicus - $R$. haqii component shows a marked drop around $10 \mathrm{Ma}$ (probably within NN 10 ; he uses an undefined time scale), with a correlative increase in the D.minutus component (his figs. $6 \& 7$ ). This could correspond to the start of the small Reticulofenestra interval. Lohmann \& Carlson (1981) conducted a similar study of Pacific material, with arguably similar results, which they interpreted in terms of climatic control. Again, however, use of multivariate analysis and an uncorrelated numerical time-scale makes data reinterpretation tenuous.

Pujos $(1985,1987)$ recorded quantitatively variations in the abundance of reticulofenestrid species in samples from Central Pacific DSDP Sites 571 -575, Leg 85. This is the most readily comparable study to mine and the results are very similar. There is a distinct small Reticulofenestra interval $(R$. minuta dominant, and $R$. pseudoumbilicus absent) at all sites. Also the assemblages below are dominated by large to medium forms $(R$. pseudoumbilicus, $R$. minutula, $D$. perplexus and $D$. hesslandii) whilst those above are characterised by small to medium forms ( $R$. minuta, and $R$. minutula with rare $R$. pseudoumbilicus). Unfortunately the relevant interval (NN9early NN11) is represented by sediments which are stratigra- phically condensed and in which the marker discoaster species are rather rare. As a result of these factors the timing of events is rather uncertain but the Reticulofenestra assemblage development is at least broadly correlative with that seen in the Indian Ocean.

Routine Studies. Events as marked as the small Reticulofenestra interval might be expected to be detected during routine studies, however, in most cases only one or two divisions of the Reticulofenestra group are made and even semi-quantitative abundance information is not al ways given . Thus in the Indian Ocean DSDP reports the small Reticulofenestra interval can be discerned in the data given by Boudreaux (1974) for Site 223, but not in the data of Roth (1974) or Theodoridis (1984) for Site 231, or of Muller (1974) for Site 242. Of Indian Ocean Sites I did not study there is evidence for it at Site 214 (Gartner 1974), and possibly Site 220 (Boudreaux 1974). Outside the Indian Ocean the interval; is discernible in the data of Jiang \& Gartner (1984, DSDP Leg 74, S.Atlantic), and more ambiguously of Martini (1981, DSDPLeg 59, Central Pacific); but few of the reports checked contain suitable information from the relevant interval.

Analogous studies. Several workers have recently investigated size variation patterns in coccoliths of other ages and have found biostratigraphically dependable patterns, notably: Backman \& Hermelin (1986), Palaeogene Reticulofenestra; Matsuoka \& Okada (1989), Rio(1982), Gephyrocapsa; Girgis (1983), Maastrichtian Arkhangelskiella; Romein (1979), Palaeocene Cruciplacolithus.

\section{DISCUSSION OF THE SIZE VARIATION TRENDS Validity and extent}

If the size variation trends had only been documented from one site then they could have been interpreted as a preservational artifact, or even a random effect. However, since three well separated sites independently show virtually the same pattern the most reasonable explanation is that these patterns represent primary variation in the nannofossil population within the study area, i.e. low latitude Western Indian Ocean.

The evidence from published work, discussed above, is not conclusive but does suggest that the small Reticulofenestra interval is also discernible in the Eastern Indian Ocean (Site 214), the Central Pacific and the South Atlantic. The contrast between the NN6-9 interval (large Reticulofenestra dominated) and the NN11-15 interval (small Reticulofenestra dominated) is harder to detect in published records, but is shown in the data of Pujos (1985). The work of Driever (1988) suggests that Mediterranean Reticulofenestra size distribution patterns were similar during the Pliocene to those of the Indian Ocean.

At high latitudes the record is complicated by poorer dating, and by the presence of forms with closed central areas, nonetheless several authors have looked closely at reticulofenestrid coccoliths from high latitude material. So it is unlikely that an event as obvious as the small Reticulofenestra interval would have gone unnoticed.

In conclusion it seems probable, that the size variation 
patters documented here may hold more or less universally at low latitudes $\left(\mathrm{c} .0-30^{\circ}\right)$, but it is likely that they are at least modified at higher latitudes.

\section{Possible Causes}

The size variation patterns can be interpreted in a range of ways. The two extreme possibilities are, first, that they represent the effect of change in ecological factors such as climate on a genetically unchanging population. Second, that they reflect evolutionary change without environmental change. It is not possible to decide conclusively between these, and the spectrum of intermediate possibilities, without information on a range of other topics including: how widespread these changes are, particularly at high latitudes; the biological significance of coccolith size variation; and how climate changed during the Neogene. At present there is too much uncertainty in all these topics for conclusions based on them to be meaningful. Indeed arguments could be constructed from present knowledge to support either of the two extreme possibilities.

Nonetheless, since size range and modal size vary independently it seems reasonable to suggest that the patterns should not be interpreted in terms of a simple response to a single external factor, such as temperature. Also a simple ecological control might be expected to produce much less stable patterns. My suspicion is that the direct control is evolutionary, i.e. that the size variation patterns are a product of genotypic variation. An ecological influence (as opposed to control) is, however, extremely likely.

\section{Taxonomic Interpretation}

In the preceding discussion I have avoided taxonomic subdivision of the group, however, for may purposes taxonomy is essential. Unfortunately there are may different possible ways of dividing the group depending on both taxonomic philosophy and the causal interpretations discussed above. In Figure 7 three hypothetically possible schemes are illustrated based on rigorous application of different premises. In Figure 7/D a suggested compromise is given.

Purely morphological. In Figure 7/A a strictly morphological classification is shown based on convenient size divisions. This has the advantage of being objective and can be used to convey observations on size variation concisely and consistently. It is, however, an explicitly arbitrary classification which does not reflect any possible evolutionary trends.

Evolutionary, monospecific. Figure 7/B shows the very different result of using an age related classification based on the assumption that the events at the end of NN15 and within NN10 constitute natural breaks within an evolving lineage. This approach has the considerable advantage that all members of a single taxon of a single age are given the same name. It has the practical disadvantage that identical specimens of different ages may be assigned to different taxa and so can only be named when the age of the sample has been determined.
Evolutionary polyspecific. Figure $7 / \mathrm{C}$ shows a third possibility, based on the assumption that the variation is due to a number of separate taxa being present at most intervals. On this basis it is most important to describe the typical form of each taxon, and to trace how this varies through time. The definitions of boundaries between taxa are less important, since it is to be expected that some overlap in the size of taxa may occur. This model is only valid if the taxa are genuine species, which is by no means certain since despite occasional bimodality there is a continuous range of variation in size and other criteria do not provide independent support for division into these taxa.

Discussion, compromise scheme. Each of these schemes has some validity, and is attractive in some respects, and for some purposes; but a single scheme needs to be adopted in order that nomenclature has any meaning - note the very different extents of $R$. pseudoumbilicus in the three diagrams (Figs. 7/ A-C).

Separation of the larger specimens ( $>3$ microns) in the Late Pliocene group is almost certainly justifiable, since associated with the change in size variation is a parallel change in the structural variability of the group. In addition to simple reticulofenestrids $R$. lacunosa morphotypes appear, with slitted shields, lower ellipticity and wider central areas. Apparently an evolutionary change in the variation potential of the group occurred at this interval and so it seems wholly reasonable to divide the lineage at this level, as on Figure 7/B. Identical coccoliths nonetheless do occur above and below the boundary.

In the NN1 1-NN15 interval the three-fold minuta - haqii pseudoumbilicus division as proposed by Backman seems to be justified by the data, although due to the presence of intermediates between these groups and the lack of independent evidence for them being separate I am inclined to regard them as varieties rather than species.

In the NN6-NN9 interval these divisions have less justification. The five micron division between $R$. haqii and $R$. pseudoumbilicus often corresponds to the peak of the unimodal size frequency distributions of this interval. Thus it is tempting to use different taxonomy for this interval, as per Figure $7 / \mathrm{C}$. However, there is no independent evidence that the small Reticulofenestra interval is an evolutionary event, so this approach which requires the creation of new taxa, or radical revision of the definitions of old ones, would be premature. If further research proves that the small Reticulofenestra interval is an evolutionary break, as suggested in Figures $7 / \mathrm{B}, \mathrm{C}$ it would then be appropriate to revise the taxonomy. For the present I suggest the compromise indicated on Fig. 7/D, applying perhaps artificially, the Late Miocene-Pliocene taxa to this interval since they do permit objective description of the assemblages, and can be used to investigate the changes in them.

\section{Biostratigraphic use}

Biostratigraphic application is more straightforward than 


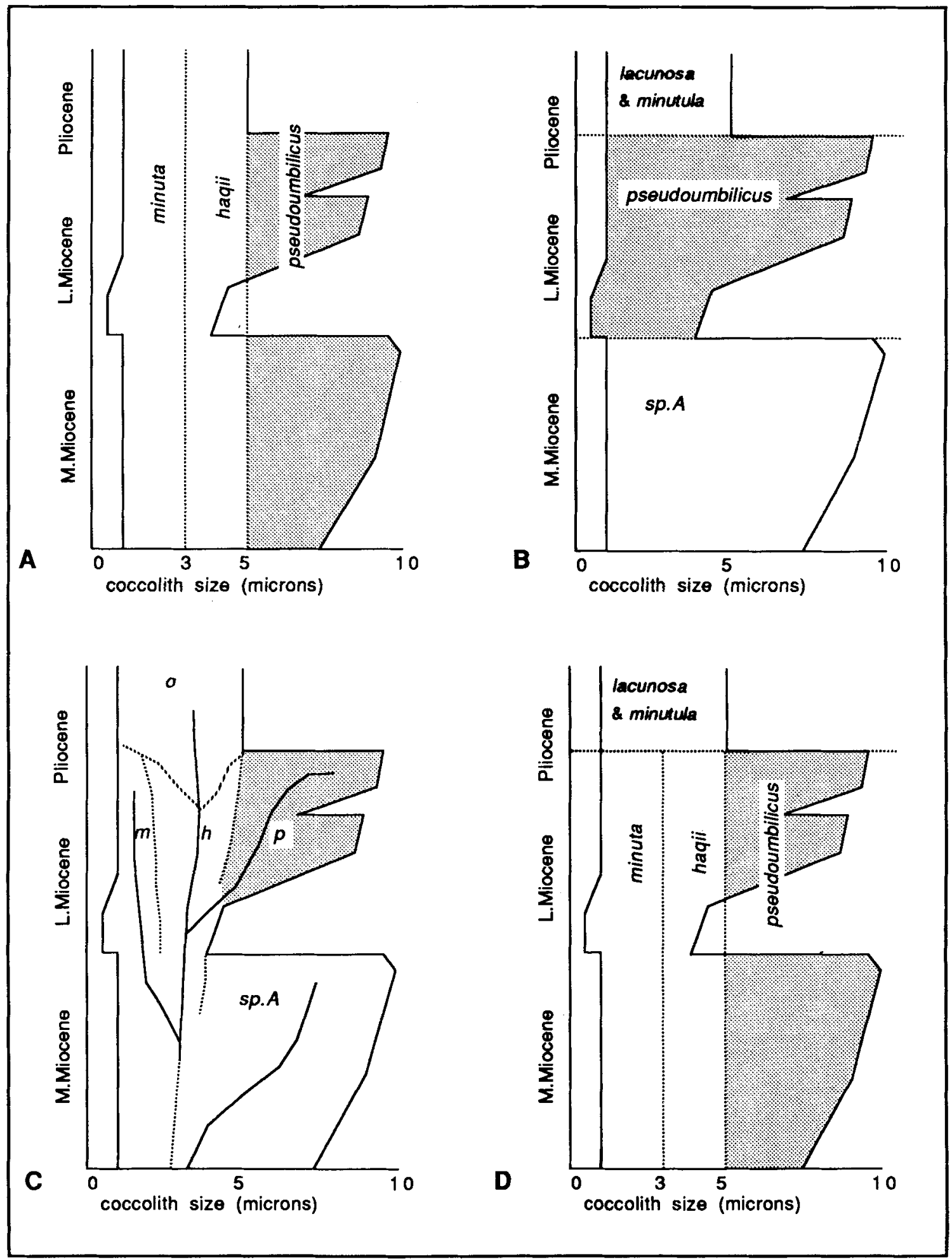

Fig. 7. Taxonomic interpretations of reticulofenestrid size variation. Four possible subdivisions of the Middle Miocene to Pliocene Reticulofenestra plexus, see text for discussion. In each diagram the size variation pattern observed in this study is indicated by the solid outline, dotted lines represent possible taxonomic subdivisions of this morphology-time space.

A. Purely morphological subdivision.

B. Evolutionary subdivision, assuming a single species, and that pattern is universally valid.

C. Evolutionary subdivision, assuming a several species are present, and that pattern is universally valid.

D. Proposed compromise scheme. 


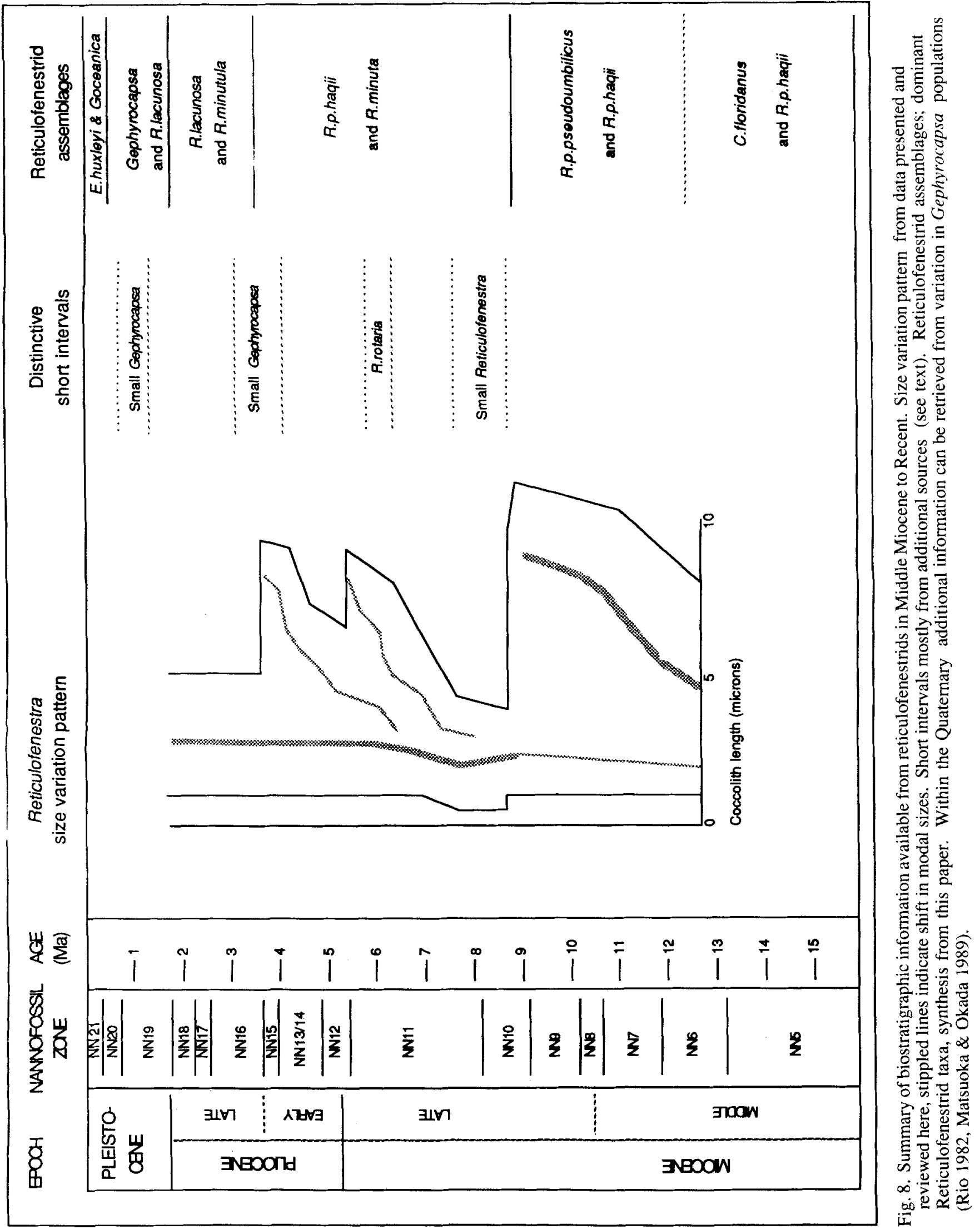


taxonomic or casual analysis, since the patterns can be applied independently of any interpretations, although it would be nice to have a theoretical basis. Figure 8 summarises the biostratigraphic data available in the mid-Miocene to Recent interval, from reticulofenestrids. Some published information not discussed above is included in this synthesis. Five main assemblages can be recognised:

A. Cyclicargolithus floridanus and medium Reticulofenestra pseudoumbilicus), NN5-6. Assemblages characterised by $C$. floridanus and medium (c.5micron) $R$. pseudoumbilicus. $C$. floridanus dominates Oligocene and Early Miocene nannofloras then is rather gradationally replaced by $R$. pseudoumbilicus. The last $C$. floridanus specimens occur in NN6 (Theodoridis 1984, my obs.).

\section{B. Medium and large Reticulofenestra pseudoumbilicus,} NN6-9.

Assemblages dominated by specimens $>4$ microns long. There appears to be a gradual increase in modal size during this interval, although maximum size does not change greatly. C. Small and medium Reticulofenestra, NN10-15. Assemblages dominated by specimens $<5$ microns long with a tail of larger specimens. Within this episode the small Reticulofenestra interval is characterised by absence of large specimens, and by very low modal size. Near the top of NN 1 I there is a short interval in which nearly circular $R$. pseudoumbilicus specimens, $R$. p.rotaria, are present (Theodoridis 1984, my obs.).

D. Reticulofenestra minutula and R. lacunosa, NN16-18. Assemblages dominated by the $R$. minutula - lacunosa species plexus (R.minutula, R.l. ovata, R.l. lacunosa). These are less than 5 microns long in the Pliocene, and the most extreme form, R.l. lacunosa, has very characteristic morphology. In addition small (<3micron) Gephyrocapsa specimens are often present. This is particularly so in NN 15 and the lowest part of NN16 (Samtleben 1978, Driever 1988, my obs.). The transition from $R$. pseudoumbilicus to $R$. minutula - lacunosa $(+$ Gephyrocapsa) flora is complex and gradational in detail (Driever 1988).

E. Gephyrocapsa, NN19-21. Assemblages dominated by Gephyrocapsa spp. with E. huxleyi in the youngest and R.lacunosa in older assemblages. This interval has been well studied and a very high resolution largely reticulofenestrid based zonation developed (Gartner 1977, Raffi \& Rio 1979, Samtleben 1980, Matsuoka \& Okada 1989).

For high resolution biostratigraphy the most interesting new feature in the floral sequence is the sharp drop in size at the beginning of the small Reticulofenestra interval. This seem to occur consistently within zone NN10. If it proves to be widely recognisable it should form a valuable addition to the standard nannofossil zonations. The minor $R$. p. rotaria and mid-Pliocene small Gephyrocapsa intervals may also prove useful (cf. Theodoridis 1984, Driever 1988). The general succession of assemblages is probably too gradational for high resolution work. Nonetheless it can be used for low resolutional work, to crudely date problematic samples or, more realistically, to test tentative age assignments based on other criteria. It proved of real utility in this way in later studies of Makran material. For such dating it is not usually necessary to measure systematically a large number of specimens, since the distribution patterns are very different between the assemblages. A graticule is of course essential.

\section{PRINCIPAL CONCLUSIONS}

1. There are consistent variations in the size-frequency distribution patterns of Reticulofenestra coccoliths in the Neogene of the Western Indian Ocean.

2. The most prominent feature of this variation, the "small Reticulofenestra interval" can be detected in the data of other workers and is probably a widespread low-latitude event.

3. The Reticulofenestra coccoliths from above and below this interval show different size distribution patterns, but otherwise seem to be morphologically similar.

4. The start of the small Reticulofenestra interval, and the contrast in assemblages above and below it, have real biostratigraphic use, as a supplement to existing schemes.

5. Further work on this topic is needed to determine the extent, causes and taxonomic significance of the changes.

6 . The success of this study suggest that equivalent studies on other nannofossil groups may be worthwhile.

\section{SYSTEMATIC DESCRIPTIONS}

The nomenclatural taxonomy of Reticulofenestra is extremely, confused, so discussion is needed here (see also Backman 1980, Pujos 1987, Driever 1988, Gallagher 1989). The system presented is based on the premise that if it is useful to arbitrarily sub-divide a continuous plexus then it is better to distinguish the taxa as varieties than species, this aspect is further discussed elsewhere (Young 1987, and in prep.). The scheme is summarised in Figures 7/D and 9. Only the genus Reticulofenestra is discussed here, and only Neogene species.

\begin{tabular}{|ll|ll|}
\hline Interval & species & varieties & diagnoses \\
\hline LATE PLIOCENE & R.lacunosa & $\begin{array}{l}\text { R.l.lacunosa } \\
\text { R.l.ovata }\end{array}$ & $>12$ slits \\
& & & $1-12 \mathrm{slits}$ \\
& R.minutula & no slits \\
\hline EARLY PLIOCENE & R.pseudoumbilicus & R.p.rotaria & circular \\
- MIOCENE & & $\begin{array}{l}\text { R.p.haqii } \\
\text { R.p.pseudoumbilicus }\end{array}$ & $3-5 \mu \mathrm{m}$ \\
& & & $<5 \mathrm{~m}$ \\
& R.minuta & & $<3 \mu \mathrm{m}$ \\
\hline
\end{tabular}

Fig. 9. Summary of taxonomic subdivision of Neogene Reticulofenestra coccoliths as proposed in this paper.

CLASS Prymnesiophyceae Hibberd 1976

FAMILY Noelaerhabdaceae Jerkovic 1970

Family including Noelaerhabdus, Reticulofenestra, Gephyrocapsa,Cyclicargolithus etc., Synonyms Prinsiaceae, Gephycapsaceae, Since the family includes the Palaeogene genera Toweius and Prinsius which have rather more complex structures the term reticulofenestrids is used informally in this paper to designate the Neogene members of the family.

Genus Reticulofenestra Hay, Mohler \& Wade 1966 
As discussed above there is a major evolutionary change in reticulofenestrid assemblages around the NN15/16 boundary and so it is convenient to divide the Reticulofenestra lineage at this point, using different species names above and below the boundary, even though some morphotypes may be indistinguishable. The two segments of the lineage are discussed separately.

\section{MID-MIOCENE AND EARLY PLIOCENE SPECIES}

This segment of the lineage is divided by the small Reticulofenestra interval, but it is impossible to distinguish individual coccoliths from above and below the small Reticulofenestra interval and it is quite possible that the larger forms became geographically restricted during the small Reticulofenestra interval, rather than extinct. So the same taxonomy is applied throughout this time period.

\section{Reticulofenestra minuta Roth 1970}

1970 Reticulofenestra minuta Roth: 850, pl. 5, Figs. 3-4.

1971 Prinsius minutus Haq: 78, pl. 6, Figs. 4-5.

1980 Reticulofenestra minuta Roth; Backman:58, pl.7, Figs. 1-3. Description. Very small elliptical Reticulofenestra species, less than 3 microns long.

Dimensions. 1.5-3 microns.

Remarks. The holotype of this species is Oligocene, but the epithet has been extensively used in this sense. In some samples R.minuta appears quite distinct from R.p.haqii, in others there is a complete morphological gradation.

Coccoliths taganus Fonseca 1976 is similar, but with a closed central area. In the Late Pliocene and Pleistocene $R$. minuta is largely replaced by the small Gephyrocapsa plexus.

\section{Reticulofenestra pseudoumbilicus (Gartner 1967) Gartner} 1969

Remarks. This species varies considerably in size, so it is convenient to subdivide it into two varieties. Forms with closed central areas are of importance at high latitudes, and a parallel set of varieties might usefully be used for them.

\section{Reticulofenestra pseudoumbilicus Gartner 1967 var. pseudoumbilicus}

1967 Coccolithus pseudoumbilicus Gartner: 4, pl. 6, Figs. 1-4. 1969 Reticulofenestra pseudoumbilicus Gartner: 598, pl. 2, Fig. 4.

Description. Medium to large elliptical variety of $R$. pseudoumbilicus, over 5 microns long.

Remarks. The holotype of $R$. pseudoumbilicus was described from Pliocene sediments of probable NN15 age.

Dimensions. 5-10 microns (occasionally up to 12 microns).

Reticulofenestra pseudoumbilicus var. haqii Backman 1978 n. stat.

1978 Reticulofenestra haqii Backman: 29, pl. 1, Figs. 1-4, pl. 2, Fig. 10.
1978 Reticulofenestra sp. Haq \& Berggren: 1 190, pl. 1, Figs. 2326.

Description. Small elliptical variety of R. pseudoumbilicus. Dimensions. 3-5microns

Remarks. The name $R$. minutula is often used in this sense but the holotype of $R$. minutula has a wide central area and reduced ellipticity, the paratypes have slitted shields, and $R$. lacunosa occurred in the type material. I believe it is a member of the $R$. lacunosa group. So use of the epithet minutula is not appropriate for $R$. pseudoumbilicus varieties.

Reticulofenestra pseudoumbilicus var. rotaria (Theodoridis 1984). n.stat.

$1984 R$. rotaria Thodoridis: 85 . pl. 5, Figs. 1-4.

Description. Medium sized, circular, or very weakly elliptical, variety of $R$. pseudoumbilicus with a wide central opening.

Dimensions. 5-7microns

Remarks. The shape of this species sharply distinguishes it from normal $R$. pseudoumbilicus. Nonetheless it is identical in other respects and intermediates between the two varieties occurred in all the samples in which I found it. Hence I consider it a variety of $R$. pseudoumbilicus rather than a separate species.

Range. Short interval near the top of the NN11 Zone $(=R$. rotaria subzone of Theodoridis 1984), my observations agreed well with those of Theodoridis.

\section{LATE PLIOCENE SPECIES}

Within the Late Pliocene there are three basic reticulofenestrid morphotypes; forms with a bridge over the central area, Gephyrocapsa; forms with slits in the distal shield, variously termed $P$ seudoemiliania lacunosa, Emiliania ovata and $E$. annula; and simple forms with neither bridge nor slits, usually termed Reticulofenestra minutula or $R$. doronicoides. Gephyrocapsa is not discussed here, the other two forms are.

The presence of slits in the distal shield has been taken as a genotypic character, however, there is a continuous variation from large sub-circular coccoliths with many slits through medium sized moderate ellipticity coccoliths with a few slits to small elliptical coccoliths with no slits (McIntyre et al., 1967, Samtleben 1979, Young 1989). This appears to be a good example of an allometric relationship between coccolith size and morphology within one species. It is quite different to the size - morphology relationship in $R$. pseudoumbilicus, where increasing size results in minimal morphological change. Uniting all the forms as varieties of one species is tempting but would result in confusing nomenclature, and there is evidence that in the Pleistocene the forms become distinct. However, the continuity of the variation certainly makes it inappropriate to place the forms in separate genera. For this reason they are all placed in Reticulofenestra.

Reticulofenestra minutula (Gartner 1967) Haq \& Berggren 1978. 
non Coccolithus doronicoides Black \& Barnes 1961: 142, pl. 25, Fig. 3.

1967 Coccolithus minutulus Gartner: partim: 3, pl. 5, Figs. 3-4. 1971 Gephyrocapsa reticulata Nishida: 150, pl. 17, Figs. 1-7. 1973 Crenalithus doronicoides (Black \& Barnes); Roth: 731, pl. 3, Fig. 3.

1978 Reticulofenestra minutula (Gartner); Haq \& Berggren: 1190.

1979 Crenalithus doronicoides (Black \& Barnes); Samtleben; 919 , pl. 3, Figs. 4,9,10.

1979 Reticulofenestra japonica Nishida (non. substit. pro G.reticulata); 105, pl. 1. Figs. 1-3

1980 Reticulofenestra japonica Nishida; Nishida: 105, pl. 1, Figs. 1,5,17.

1980 Reticulofenestra minutula (Gartner); Backman: 59, pl. 7 , Figs. 3-5, 11,13.

1985 Reticulofenestra doronicoides (Black \& Barnes); Pujos (invalid): 594, pl. 1, Fig. 7

1987 Reticulofenestra doronicoides (Black \& Barnes); Pujos: 247, pl. 1, Figs. 13-17.

1988 Reticulofenestra minutula (Gartner); Driever: 117, pl. 1, Fig. 1, pl. 5, Figs. 3-6.

1988 Reticulofenestra doronicoides (Black \& Barnes); Young 1988:4.

Emended Diagnosis. Small elliptical Reticulofenestra species, without slits in the distal shield.

Dimensions. 3-5microns

Remarks. $R$. minutula specimens usually have wider central areas than typical R.p.haqii specimens, but this distinction is not of much practical use, distinction of the two is primarily by means of associated larger coccoliths.

The epithet doronicoides has often been used for this species, but the true identity of the holotype of Coccolithus doronicoides has been in doubt (Backman 1980). To resolve this point the topotypic material, Challenger dredging 338, was re-examined. The material is calcareous ooze with a well preserved Holocene nannoflora, and virtually no reworked Neogene material. The "discoasters" referred to in Black \& Barnes (1961) are in fact coccoliths of the extant species Hayaster perplexus.

The only coccoliths matching the illustration and description of C.doronicoides appear to be specimens of Gephyrocapsa oceanica which have lost their bridge. So C. doronicoides should be considered a junior synonym of $G$. oceanica. This leaves $R$ minutula as the name with priority.

\section{Reticulofenestra lacunosa (Gartner 1969, ex Kamptner 1963) n.comb.}

1963 Ellipsoplacolithus lacunosus Kamptner: 172, pl. 9, Fig. 50.

1969 Pseudoemiliania lacunosa (Kamptner); Gartner: 595, pl. 2, Figs. 9-10.

Description. Species of Reticulofenestra with a variable number of irregular slits in the distal shield.

Remarks. Kamptner (1963) described Ellipsoplacolithus lacunosus as a paraspecies (provisional taxon), and so it was invalid (Loeblich \& Tappan 1967). Gartner (1969) used the epithet in a non-provisional sense, and as the type species of his genus Pseudoemiliania. The validity of this has been disputed (Loeblich \& Tappan 1970, Gartner 1977), leading to rather variable taxonomic usage. Careful re-examination of the original descriptions in the light of the latest version of the ICBN (Greuter et al., 1988) suggests that Gartner (1969) did validate lacunosa, and so this epithet does have priority over ovata, (S.E. van Heck pers comm 1989, and in press).

The species is strongly variable and there is a tendency for the larger more circular forms with more slits to become more common through time. So it is sometimes useful to divide the species; the degree of slitting is visible by light microscopy in reasonably well preserved material, and forms the most convenient arbitrary criterion for division.

\section{Reticulofenestra lacunosa (Gartner 1969 ex Kamptner 1963). n.comb. var. lacunosa}

1963 Ellipsoplacolithus lacunosus Kamptner: 172, pl. 9, Fig. 50. 1969 Pseudoemiliania lacunosa (Kamptner); Gartner: 598, pl. 2, Figs. 9-10.

1971 Emiliania annula (Cohen); Bukry: 1971, 1514.

1977 Pseudoemiliana lacunosa (Kamptner); Gartner: 15, pl. 4, fig. 3.

1979 Pseudoemiliana lacunosa (Kamptner); Samtleben: 919, pl. 3, figs. 2, 5, 12.

1980 Pseudoemiliana lacunosa (Kamptner); Nishida: pl. 1, Fig. 13.

1988 Emiliania ovata Bukry 1973; Driever (partim): pl. 6, Figs. 6-11, pl. 7, Figs. 1, 2, 5, 6, 8.

Emended Diagnosis. Circular to sub-circular variety of $R$. lacunosa with more than twelve slits in the distal shield.

Remarks. Use of the epithet annula for this form was based on misidentification of the holotype of Cyclococcolithus annulus Cohen 1964, which was probably a specimen of Neosphaera coccolithormorpha Lecal-Schaudler (1950). Similarly the holotype of Coccolithus cricotus Gartner 1967 was probably a coccolith of Geminilithella rotula.

Size. c. 4-8microns.

Reticulofenestra lacunosa var. ovata (Bukry 1973) n.comb. \& stat.

1967 Coccolithus minutulus Gartner partim: pl. 5, figs. 3, 4, non. p. 3, pl. 5, Figs. 3-5.

1973 Emiliania ovata Bukry: 678, pl. 2, Figs. 10-12.

1973 Pseudoemiliania lacunosa (Kamptner) Gartner; Roth: pl. 3, fig. 6.

1979 Pseudomiliana lacunosa (Kamptner) Gartner; Samtleben: 919 , pl. 3, Figs. 2, 3, 5, 6.

1979 Reticulofenestra pacifica Nishida: 106, pl. 1, Figs. 4-6.

1980 Reticulofenestra pacifica Nishida; Nishida; pl. 1, Fig. 9.

1980 Pseudomiliana lacunosa (Kamptner) Gartner; Backman: pl. 16, Figs. 12,13.

1988 Emiliana ovata Bukry; Driever partim: pl. 1, Fig. 2, pl. 7, Figs. 3,4,7.

Emended diagnosis: Elliptical variety of $R$. lacunosa with less than twelve slits in the distal shield.

Size: c.3.5-5.5 microns. 


\section{ACKNOWLEDGEMENTS}

The Deep Sea Drilling Project panel made available the material on which this study was based. It was financially supported by the Natural Environment Research Council. Katharina Perch-Nielsen, Alan Lord, John Whittaker, and an anonymous reviewer read drafts of the manuscript and made valuable suggestions.

\section{Manuscript received: May 1989 \\ Revised manuscript accepted January 1990}

\section{REFERENCES}

Backman, J. 1978. Late Miocene and Early Pliocene nannofossil biochronology and biogeography in the Vera Basin, S.E. Spain, Stockh. Contr. Geol. 32, 993-114.

Backman, J. 1980. Miocene - Pliocene nannofossils and sedimentation rates in the Hatton - Rockall Basin, NE Atlantic Ocean. Stockh. Contr. Geol. 36, 1-93.

Backman, J. 1984. Cenozoic calcareous nannofossil biostratigraphy from the North Eastern Atlantic Ocean, DSDP Leg 81 , IRDSDP, 81, 403-428.

Backman, J. \& Hermelin, J. O. R. 1986. Morphometry of the Eocene nannofossil Reticulofenestra umbilicus and its biochronological consequences. Palaeogeogr. Palaeoclimatol. Palaeoecol., 57, 103-116.

Black, M. \& Barnes, B. 1961. Coccoliths and discoasters from the floor of South Atlantic Ocean. J.R. microsc. Soc., 80, 137 147.

Boudreaux, J. E. 1974. Calcareous nannoplankton ranges DSDP Leg 23. IRDSDP, 23, 1073-1090.

Bukry, D. 1971. Coccolith stratigraphy, Leg. 7 DSDP. IRDSDP, 7, 1513-1518.

Bukry, D. 1973. Coccolith stratigraphy, East Equatorial Pacific, Leg 16 DSDP. IRDSDP, 16, 653-711.

Burns, D. A. 1975. Distribution abundance and preservation of nannofossils in Eocene to Recent Antarctic sediments. N.Z.J. Geol Geophys., 18, 583-595.

Burns. D. A. 1977. Phenotypes and dissolution morphotypes of the genus Gephyrocapsa and Emiliania huxleyi (Lohmann). N.Z. J. Geol. Geophys., 20, 143-155.

Cohen, C. L. D. 1964. Coccolithophorids from two Caribbean deep-sea cores. Micropalaeontology, 10, 231-250.

Davies, T. A., Luyendyk, B.P. et al., 1974. Initial Reports of the Deep Sea Drilling Project, Volume XXVI, Washington (U.S. Government Printing Office) IRDSDP 26.

Driever, B.W. M. 1988. Calcareous nannofossil biostratigraphy and paleoenvironmental interpretation of the Mediterranean Pliocene. Utrecht. Micropalaeont. Bull., 36, 1-245.

Fisher, R.L., Bunce, E. T. et al., 1974. Initial Reports of the Deep Sea Drilling Project, Volume XXIV, Washington (U.S. Government Printing Office). IRDSDP 24.

Fonseca, B. 1976. Notes sur la géologie et paléontologie du Miocène de Lisbonne,XVII. Coccolithus taganus, nouvelle espèce de coccolithophoridé du Miocène de Lisbonne. Bolm. Soc. Geol. Port., 20, 29-31.

Gallagher, L. 1989. Reticulofenestra: A critical review of taxonomy and evolution. In. Crux, J. \& van Heck, S. E. (eds.) Nannofossils and their applications, Proceedings Second International Nannoplankton Association Symposium, London 1987, 41-45.

Gartner, S. 1967. Calcareous nannofossils from the Neogene of Trinidad, Jamaica and Gulf of Mexico. Paleont. Cont. Univ. Kansas, Paper 29, 1-7.
Gartner, S. 1969. Correlation of Neogene planktonic foraminifera and calcareous nannofossil zones. Trans Gulf Cst. Ass. Geol. Socs., 19, 585-599.

Gartner, S. 1974. Nannofossil biostratigraphy, Leg 22, DSDP. IRDSDP, 22, 511-61.

Gartner, S. 1977. Calcareous nannofossil biostratigraphy and revised zonation of the Pleistocene, Mar. micropaleont., 2, 125 .

Girgis, M. H. 1989. A morphometrical analysis of the Arkhangelskiella group and its stratigraphical and palaeoenvironmental importance. In. Crux. J. \& van Heck, S. E. (eds.) Nannofossils and their applications, Proceedings Second International Nannoplankton Association Symposium, London 1987, 327-339.

Greuter, W. et al., 1988. International Code of Botanical Nomenclature, Berlin 1987. Koeltze Scientific Books, FRG, p1-328.

Haq, B. U. 1971. Paleogene calcareous nannoflora. II, Oligocene of Western Germany. Stockh, Contr. Geol. 25, 57-97.

Haq, B. U. 1980. Biogeographic history of Miocene calcareous nannoplankton and paleo-oceanography of the Atlantic Ocean. Micropaleontology 26, 414-443.

Haq, B. U., Hardenbol, J., \& Vail,. R. 1986. Chronology of fluctuating sea levels since the Triassic ( 250 million years ago to the present). Science, 235, 1156-1167.

Haq, B. U. \& Berggren, W. A. 1978. Late Neogene calcareous nannoplankton biochronology of the Rio Grande Rise (S. Atlantic). J. Paleont., 52, 1167-1194.

Hay, W. W., Mohler, H. P. \& Wade, M. E. 1966. Calcareous nannofossils from the Nal'Chik (NW Caucasus). Eclog. geol. Helv. 59, 379-401.

Heck, S. E. van. in press: On the validity of Pseudoemiliania lacunosa Kamptner 1963 ex Gartner 1967. Newsl. Internat. Nannoplankton Assoc. 12/2.

Heimdal, B. R. \& Gaarder, K. R. 1981. Coccolithophorids from the northern part of the eastern central atlantic. Heterococcolithophorids. Meteor Forsch. Ergben . D33, 3769.

Hibberd, D. J. 1976. The ultrastructure and taxonomy of the Chrysophyceae and Prymnesiophyceae (Haptophyceae): a survey with some new observations on the ultrastructure of the Chrysophyceae. Bott. J. Linn. Soc.,72, 55-80.

Jerkovic, M. L. 1970. Noelaerhabdus nov. gen. type d'une nouvelle famille de Coccolithophoridées fossiles: Noelaerhabdaceae du Miocène supérieur de Yougoslavie. C.r. hebd. Séanc: Acad. Sci. Paris, 270, 468-470.

Jiang, M. J. \& Gartner, S. 1984. Neogene and Quaternary calcareous nannofossil biostratigraphy of the Walvis Ridge. IRDSDP, 74, 561-595.

Kamptner, E. 1963. Coccolithineen - Skeletreste aus Tiefseeablagenungen des Pazifischen Ozeans. Annln. natur. Mus. Wien, 66, 139-204.

Lecal-Schaudler, J. 1950. Notes préliminaires sur le coccolithophoridés d'Afrique du Nord. Bull. Soc. Nat. Afr. Nord., 40, $160-167$

Loeblich, A. R. \& Tappan, H. 1970. Annotated index and bibliography of the calcareous nannoplankton IV.J.Paeontol., 44, 584-598.

Lohmann, G. P. \& Carlson, J. J. 1981. Oceanographic significance of Pacific Late Miocene calcareous nannoplankton. Mar. micropaleont., 6, 553-579.

McIntyre, A. Bé, A. W. H. \& Preiksitas, R. 1967. Coccoliths and the Pliocene-Pleistocene boundary. Progr. Oceanogr., 4, 3 25 . 
Martini, E. 1971. Standard Tertiary and Quaternary calcareous nannoplankton zonation. In, FARINACCI A. (Ed.): Procs. II Plkt. Conf., Roma 1070, 2, p. 739-786.

Martini, E. 1981. Oligocene to Recent calcareous nannoplankton from the Phillipine Sea, DSDP Leg 59. IRDSDP, 59, 547565.

Matsuoka, H. \& Okada, H. 1989. Quantitative analysis of Quaternary nannoplankton in the subtropical North West Pacific Ocean. Marine Micropalaeontology, 14, 97-118.

Muller, C. 1974. Calcareous nannoplankton, DSDP Leg 25. IRDSDP. 25, 579-635.

Nishida, S. 1971. Nannofossils from Japan IV. Calcareous nannofossils from the Tonohama Group, Shikoku, S.W. Japan. Trans. Proc palaeont. Soc. Japan, N.S., 83, 143-161.

Nishida, S. 1979. Restudies of the calcareous nannoplankton biostratigraphy of Tonohama Group, Shikoku, Japan. Bull. Nara Univ. Education. 28, 97-110.

Nishida, S. 1980. Calcareous nannoplankton biostratigraphy around the Pliocene - Pleistocene boundary in the southern part of Okinawa - jima, Japan. Chishitsugaku Zasshi, 86, 525536.

Okada, H. \& Bukry, D. 1980. Supplementary modification and introduction of code numbers to the low latitude coccolith biostratigraphic zonation (Bukry 1973, 1975). Mar. Micropaleont., 5, 321-325.

Perch Nielsen, K. 1985. Cenozoic calcareous nannofossils. In. Bolli, H. M., Saunders J. B., \& Perch-Nielsen, K. (eds.). Plankton stratigraphy, Cambridge University Press, 329426.

Platt, J. P., Leggett, J. K., Young, J. R., Raza, H. \& Alam, S. 1985. Large-scale sediment underplating in the Makran accretionary prism, southwest Pakistan. Geology, 13, 507 511.

Pujos, A. 1985. Cenozoic nannofossils from the central equatorial Pacific, DSDP Leg. 85. IRDSDP 85, 581-607.

Pujos, A. 1987. Late Eocene to Pleistocene medium-sized and small-sized "Reticulofenestrids". In, Stradner H. \& PerchNielsen K. (Eds.): Procs. Int. Nannoplankton Ass. Meeting, Vienna 1985. Abh. geol. Bundesanst., 39, 239-277.

Raffi, I. \& Rio, D. 1979. Calcareous nannofossil zonation of DSDP Site 132 - Leg 13 (Tyrrhenian Sea - Western Mediterranean). Riv. Ital. Palaeont. Stratigr., 85, 127-172.
Rio, D. 1982. The fossil distribution of coccolithophore genus Gephyrocapsa Kamptner and related Pliocene - Pleistocene chronostratigraphic problems. IRDSDP 68, 325-346.

Romein, A. J. T. 1979. Lineages in the early Palaeogene calcareous nannoplankton. Utrecht micropal. Bull., 22, 1231.

Roth, P. H. 1970. Oligocene calcareous nannoplankton biostratigraphy. Eclog. geol. Helv., 63, 799-881.

Roth, P. H. 1973. Calcareous nannofossils - Leg 17, DSDP. IRDSDP 17, 695-795.

Roth, P. H. 1974. Calcareous nannofossils from the north west Indian Ocean, Leg 24 DSDP. IRDSDP 24, 969-994.

Samtleben, C. 1979. Pliocene to Pleistocene coccolith assemblages from the Sierra Leone Rise, Site 366, Leg 41. IRDSDP 41, 913-9311.

Samtleben, C. 1980. Die evolution de Coccolithophoriden Gattung Gephyrocapsa Nach Befunden im Atlantik. Palaont. Z., 54,91-127.

Simpson, E. S. W. \& Schlich, R. ef al.. 1974. Initial Reports of the Deep Sea Drilling Project, Volume XXV Washington (U.S. Government Printing Office), IRDSDP 25.

Theodoridis, S. 1984. Calcareous nannofossil biostratigraphy of the Miocene and revision of the helicoliths and discoasters. Utrecht Micropaleont. Bull., 32, 1-271.

Whitmarsh, R. B., Weser, O. E., Ross, D. A. et al., 1974. Initial Reports of the Deep Sea Drilling Project, Volume XXIII, Washington (U.S. Government Printing Office). IRDSDP 23.

Wise, S. E. 1983. Mesozoic and Cenozoic calcareous nannofossils recovered by DSDP leg 71 in the Falkland Plateau region, SW Atlantic Ocean. IRDSDP 71/2, 481-551.

Young, J. R. 1987. Neogene calcareous nannofossils from the Makran of Pakistan and the Indian Ocean. Unpublished PhD thesis, University of London p. 1-288.

Young, J.R. 1988. Taxonomic note, validation of the combination Reticulofenestra doronicoides (Black \& Barnes 1961). Int Nannoplankton Assoc. Newsl. 9/1, p. 3.

Young, J. R. 1989. Observations on heterococcolith rim structure and its relationship to developmental processes. In. Crux, J. \& van Heck, S. E. (eds.) Nannofossils and their applications, Proceedings Second International Nannoplankton Association Symposium, London 1987, 1-20. 